\title{
Potensi Parasitoid Telur dalam Mengendalikan Wereng Batang Cokelat (Nilaparvata lugens Stal.) Pasca Ledakan Populasi di Kabupaten Banyumas
}

\section{The Potency of Egg Parasitoids in Controlling Post Explosion Population of Brown Planthopper (Nilaparvata lugens Stal.) in Banyumas Regency}

\author{
Endang Warih Minarni ${ }^{1) *}$, Agus Suyanto ${ }^{1)}$, \& Kartini ${ }^{1)}$ \\ 1) Program Studi Agroteknologi, Fakultas Pertanian, Universitas Jenderal Soedirman, \\ Jln. Dr. Suparno, Karangwangkal, Purwokerto, Jawa Tengah 53123 \\ *Penulis untuk korespondensi.E-mail: endangwarihminarni@gmail.com
}

Diterima 13 Oktober 2017; diterima untuk diterbitkan 6 Juli 2018

\begin{abstract}
This study aims to determine the type and potency of egg parasitoid in controlling brown planthopper (Nilaparvata lugens Stal.) pests in Banyumas regency after the pest's explosion. This research has been conducted in five districts of the endemic area of brown planthopper in Banyumas Regency, i.e. in Jatilawang, Cilongok, Kebasen, Sumpiuh, and Kembaran. Each of the districts was taken 5 sample villages. The testing and calculation of the level of parasitization were done in the laboratory of Plant Protection, Faculty of Agriculture, University of Jenderal Soedirman, Purwokerto. The research used nest plot design, where the first factor was the district and the second factor was the village. Village nested in district. The data were analyzed using $F$ 5\% test, followed by 5\% DMRT, if there were any differences found. The results of the study were as follows: (1) the parasitoids found in Banyumas Regency were Gonatocerus sp. and Oligosita sp. with the ability to parasite $26.8-64.73 \%$, and $1.82-31.40 \%$; (2) the presence parasitoid has the potency to suppress the intensity of brown planthopper attack on the vegetative phase, the intensity of attacks ranged between 6.96-23.58\%, with brown planthopper population ranged from 0.84 to 27.36 individuals per hill.
\end{abstract}

Keywords: Gonatocerus $s p$., Nilaparvata lugens, Oligosita $s p .$, parasitoid

\section{INTISARI}

Penelitian ini bertujuan untuk mengetahui jenis dan potensi parasitoid telur dalam mengendalikan hama wereng batang coklat (Nilaparvata lugens Stal.) di Kabupaten Banyumas pasca ledakan populasi. Penelitian ini dilaksanakan di lima kecamatan daerah endemik wereng batang cokelat di wilayah Kabupaten Banyumas yaitu Kecamatan Jatilawang, Cilongok, Kebasen, Sumpiuh, Kembaran. Masing-masing kecamatan diambil 5 desa sampel. Pengujian dan penghitungan tingkat pemarasitan dilakukan di laboratorium Perlindungan Tanaman Fakultas Pertanian, Universitas Jenderal Soedirman, Purwokerto. Penelitian menggunakan rancangan petak tersarang, dengan kecamatan sebagai faktor pertama dan desa sebagai faktor kedua. Desa tersarang pada kecamatan. Data dianalisis menggunakan uji F 5\%, apabila ada perbedaan dilanjutkan dengan uji banding ganda DMRT $5 \%$. Adapun hasil penelitian adalah sebagai berikut: (1) parasitoid yang ditemukan di Kabupaten Banyumas adalah Gonatocerus sp. dan Oligosita sp. dengan kemampuan memarasit 26,8-64,73\%, dan sebesar 1,82-31,40\%; (2) keberadaan parasitoid berpotensi menekan intensitas serangan hama wereng batang cokelat pada fase vegetatif, intensitas serangan berkisar antara $6,96-23,58 \%$, dengan populasi wereng batang cokelat berkisar 0,84-27,36 individu per rumpun.

Kata kunci: Gonatocerus sp., Nilaparvata lugens, Oligosita sp., parasitoid

\section{PENDAHULUAN}

Tanaman padi adalah salah satu komoditas pangan utama dan bersifat strategis, karena hampir 90 persen penduduk Indonesia mengkonsumsi beras. Wereng batang cokelat (Nilaparvata lugens) merupakan hama utama pada tanaman padi dan menimbulkan kerugian yang besar di semua negara penghasil beras (Cheng, 2009; Hu et al., 2012; Bottrell \& Schoenly, 2012; Hu et al., 2014; Tiwari, 2015).
Frekuensi serangan telah meningkat di negaranegara berkembang Asia pada tahun 2005-2012. Hal ini disebabkan karena terbunuhnya musuh alami akibat penggunaan insektisida yang berspektrum luas (Piyaphongkul et al., 2012; Ali et al., 2014).

Pada tahun 2017, beberapa wilayah di provinsi Jawa Barat, Jawa Tengah, Jawa Timur, dan Sulawesi Selatan rawan terjadinya ledakan hama wereng batang cokelat. Berdasarkan data Direktorat Tanaman Pangan 
total luas tanah yang terserang hama wereng batang cokelat dari Januari hinggal Juli 2017 mencapai 67.749 ha. Sementara, lahan puso (gagal panen) yang diakibatkan wereng seluas 746,71 ha (Budi, 2017).

Ledakan wereng batang cokelat dipicu oleh perubahan iklim global yang menyebabkan kelembapan yang tinggi pada musim kemarau sehingga memengaruhi pertumbuhan dan perkembangan hama wereng batang cokelat (Baehaki \& Mejaya, 2014). Selain faktor iklim perilaku petani juga memegang peranan penting terjadinya ledakan hama tersebut. Tanam tidak serempak, tidak adanya rotasi tanaman dan varietas, dan penggunaan insektisida kimia sintetis yang berlebihan memicu terjadinya ledakan hama.

Musuh alami seperti predator dan parasitoid ikut terbunuh karena penggunaan insektisida (Brunner et al., 2001; Wang et al., 2008; Preetha et al., 2010; Munawar et al., 2015; Haryati et al., 2016). Terbunuhnya musuh alami mengakibatkan populasi wereng batang cokelat akan meningkat. Salah satu musuh alami yang berperan dalam mengendalikan hama wereng batang cokelat adalah parasitoid telur. Parasitoid adalah serangga yang selama tahap pradewasanya hidup di dalam atau di permukaan tubuh serangga lain yang menjadi inangnya. Pradewasa parasitoid akan memakan bagian tubuh inangnya untuk tumbuh dan berkembang mencapai tahap dewasa. Inang akan mengalami kematian dan parasitoid dewasa akan keluar dari inang dan hidup bebas (Quicke, 1997). Meilin et al. (2012) menemukan tiga spesies parasitoid telur $N$. lugens di Klaten dan Yogyakarta yaitu Anagrus nilaparvatae, Oligosita sp., dan Gonatocerus sp., sementara Lu et al. (2006) melaporkan di Filipina ditemukan tiga jenis parasitoid dalam penelitiannya yaitu Anagrus flaveolus, Oligosita sp., dan Gonatocerus sp.. Adapun yang mendominasi adalah A. flaveolus dan Oligosita sp.. Hasil penelitian Abdillah (2015), kelimpahan relatif parasitoid telur $N$. lugens di pertanaman padi di daerah Darmaga, Bogor dalam tiga kali pemerangkapan berturut-turut adalah Anagrus nilaparvatae sebanyak 826 individu (19,87\%), Anagrus sp. sebanyak 12 individu $(0,29 \%)$, Oligosita sp. sebanyak 3.059 individu (73,60\%), Tetrastichus formosanus sebanyak 194 individu (4,67\%), Gonatocerus sp. sebanyak 47 individu (1,13\%), dan Cyrtogaster near vulgaris sebanyak 18 individu (0,43\%). Kelimpahan Oligosita sp. tertinggi dibandingkan dengan parasitoid $N$. lugens lainnya.
Kemampuan parasitoid telur wereng batang cokelat dalam mengendalikan hama wereng batang cokelat dan kemelimpahannya di lapang merupakan suatu potensi yang penting untuk dikembangkan sebagai agensia pengendali hayati. Penelitian ini bertujuan untuk mengetahui jenis dan potensi parasitoid telur dalam mengendalikan hama wereng batang cokelat di Kabupaten Banyumas pasca terjadinya ledakan.

\section{BAHAN DAN METODE}

\section{Lokasi dan Waktu Penelitian}

Penelitian ini dilaksanakan di lima kecamatan daerah endemik wereng batang cokelat di wilayah Kabupaten Banyumas, yaitu Jatilawang, Cilongok, Kebasen, Sumpiuh, dan Kembaran. Pengujian dan penghitungan tingkat pemarasitan dilakukan di Laboratorium Perlindungan Tanaman Fakultas Pertanian, Universitas Jenderal Soedirman, Purwokerto. Penelitian dilaksanakan bulan Mei sampai dengan Juli 2017. Suhu berkisar $22-33^{\circ} \mathrm{C}$; kelembapan udara $68-82 \%$.

\section{Metode Penelitian}

Penelitian ini merupakan penelitian eksplorasi yang dalam pengambilan sampelnya menggunakan metode Stratified random sampling. Kecamatan sampel dipilih karena merupakan daerah endemik hama wereng cokelat. Masing-masing kecamatan diambil 5 desa dan tiap-tiap desa diambil 5 lokasi sawah dengan tanaman padi berkisar 35 sampai 40 hari. Tanaman perangkap berumur dua minggu, diletakkan di sekitar persawahan tersebut sebanyak 10 tanaman per desa sampel dengan jarak antar tanaman perangkap $10 \mathrm{~m}$. Tanaman perangkap tidak disemprot dengan insektisida. Tanaman perangkap tidak disungkup dengan tujuan agar tidak menghalangi wereng batang cokelat dan paraitoid untuk hinggap pada tanaman perangkap dan parasitoid dapat memarasit telur wereng batang cokelat. Paparan insektisida dapat dihindari atau dikurangi dengan memberikan tanda pada ember dan tanaman sampel dengan ajir bambu, sehingga petani tidak melakukan penyemprotan pada tanaman perangkap tersebut.

Penelitian menggunakan rancangan petak tersarang, dengan faktor pertama adalah kecamatan dan faktor kedua desa. Desa tersarang pada Kecamatan. Data dianalisis menggunakan uji F 5\%, apabila ada perbedaan dilanjutkan dengan uji banding ganda 


\section{DMRT 5\%.}

\section{Persiapan Bibit Padi}

Tanaman padi yang digunakan adalah varietas Cilamaya Muncul. Benih direndam dalam air selama semalam, kemudian ditiriskan selama 24 jam. Benih padi disebar pada ember plastik berukuran tinggi 15 $\mathrm{cm}$ dengan diameter $20 \mathrm{~cm}$, yang berisi tanah dengan ketebalan $10 \mathrm{~cm}$. Tiap ember disebar 10 benih padi. Bibit padi digunakan sebagai perangkap berumur 2 minggu.

\section{Persiapan N. lugens dan Penghitungan Tingkat Pemarasitan Parasitoid Telur terhadap Telur Wereng Batang Cokelat}

Tanaman perangkap berumur 2 minggu diletakkan di persawahan dengan tanaman padi stadia vegetatif. Tanaman perangkap ditanam di dalam ember dan diberi ajir sebagai tanda agar tidak disemprot saat petani menyemprot insektisida. Masing-masing desa sampel diletakkan 10 ember tanaman perangkap. Setelah dua minggu di lahan, tanaman perangkap disungkup dan dibawa ke laboratorium. Di laboratorium, tanaman padi dipotong, diambil bagian batangnya sepanjang $15 \mathrm{~cm}$ dan dimasukkan ke dalam tabung reaksi. Pengamatan dilakukan setiap hari untuk menghitung jumlah parasitoid dan nimfa wereng batang yang muncul, untuk menghitung jumlah telur yang tidak menetas batang padi dibelah dengan hati-hati di bawah mikroskop. Parasitoid yang muncul kemudian diidentifikasi. Telur yang terparasit namun gagal menjadi parasitoid dewasa, dihitung sebagai

$$
T P=\frac{\text { Jumlah telur yang terparasit }}{\text { Jumlah telur seluruhnya }} \times 100 \%
$$

telur terparasit. Penghitungan tingkat pemarasitan (TP), dihitung dengan rumus Meilin et al. (2012):

\section{Penghitungan Intensitas Serangan dan Populasi Wereng Batang Cokelat}

Pengamatan dan penghitungan intensitas serangan dan populasi wereng batang cokelat dilakukan sebelum tanaman padi dipotong. Tiap sampel tanaman padi dari lapang, diamati jumlah wereng batang cokelat yang ada dan intensitas serangannya. Penentuan intensitas serangan wereng batang cokelat dilakukan dengan melihat gejala serangan pada tanaman perangkap. Standar tingkat kerusakan wereng batang cokelat

$$
I=\frac{\sum(n \times v)}{N \times Z} \times 100 \%
$$

dapat dilihat pada Tabel 1. Intensitas serangan dapat

$\mathrm{I}=$ Intensitas serangan (\%)

$\mathrm{n}=$ Jumlah batang dari setiap kategori serangan

$\mathrm{v}=$ Skor gejala kerusakan batang terserang

$\mathrm{N}$ = Jumlah batang yang diamati

$\mathrm{Z}=$ Nilai kategori serangan tertinggi $(\mathrm{v}=9)$

\begin{tabular}{|c|c|}
\hline $\begin{array}{l}\text { Nilai } \\
\text { Skala }\end{array}$ & Gejala Kerusakan \\
\hline 0 & Tidak ada gejala kerusakan \\
\hline 1 & Tanaman sedikit menguning \\
\hline 3 & $\begin{array}{l}\text { Daun sebagian menguning, tetapi tidak } \\
\text { ada gejala hopperburn }\end{array}$ \\
\hline 5 & $\begin{array}{l}\text { Daun-daun menguning, pertumbuhan ter- } \\
\text { hambat atau layu, } 10-25 \% \text { mengalami } \\
\text { hopperburn atau mengalami kerdil }\end{array}$ \\
\hline 7 & $\begin{array}{l}\text { Lebih dari separuh tanaman layu atau dengan } \\
\text { hopperburn atau tanaman sangat kerdil }\end{array}$ \\
\hline 9 & Tanaman padi mati \\
\hline
\end{tabular}

Tabel 1. Standar tingkat kerusakan wereng batang cokelat

Sumber: International Rice Research Institute (2002)

dihitung dengan rumus Townsend \& Hueberger (1948): Keterangan:

\section{HASIL DAN PEMBAHASAN}

Wereng batang cokelat merupakan hama utama tanaman padi. Keberadaannya di alam secara alami dikendalikan oleh musuh alaminya. Salah satu musuh alaminya adalah parasitoid telur. Parasitoid telur ini hidup menumpang di dalam telur wereng batang cokelat, setelah dewasa parasitoid akan hidup bebas dan memanfaatkan nektar dari gulma berbunga untuk makanannya. Berdasarkan hasil pengamatan dan identifikasi di wilayah Kabupaten Banyumas yang ditemukan parasitoid telur Gonatocerus sp. dan Oligosita sp.. Pemarasitan parasitoid Gonatocerus sp. terhadap telur wereng batang cokelat berkisar 26,8 $64,73 \%$, sedangkan parasitoid Oligosita sp. sebesar $1,82-31,40 \%$. Total pemarasitan telur wereng batang cokelat oleh kedua parasitoid tersebut berkisar 41,2470,84\% (Tabel 2).

Parasitoid Anagrus sp. tidak ditemukan di Kabupaten Banyumas, diduga parasitoid tersebut relatif peka terhadap insektisida yang diaplikasikan oleh petani. Petani di Kabupaten Banyumas kebanyakan menggunakan insektisida berbahan aktif klorpirifos, imidakloprid, dan tiametoksam (Tabel 6). 
Tabel 2. Tingkat pemarasitan parasitoid Gonatocerus sp. dan Oligosita sp. terhadap telur wereng batang cokelat di tiaptiap kecamatan dan desa sampel

\begin{tabular}{|c|c|c|c|c|}
\hline Kecamatan & Desa & Gonatocerus sp. & Oligosita sp. & Total pemarasitan \\
\hline \multirow{5}{*}{ Jatilawang } & Karanganyar & 46,36 & 18,39 & 64,75 \\
\hline & Margasana & 56,58 & 0,00 & 56,58 \\
\hline & Kedungwringin & 57,10 & 0,00 & 57,10 \\
\hline & Bantar & 64,73 & 6,11 & 70,84 \\
\hline & Tinggarjaya & 48,24 & 0,00 & 48,24 \\
\hline Rerata & & $54,60 \mathrm{e}$ & $4,90 \mathrm{~b}$ & $59,50 \mathrm{c}$ \\
\hline \multirow{5}{*}{ Cilongok } & Kalisari & 47,83 & 15,38 & 63,21 \\
\hline & Rancamaya & 46,39 & 3,08 & 49,47 \\
\hline & Sudimara & 41,14 & 1,82 & 42,96 \\
\hline & Panusupan & 39,08 & 19,41 & 58,49 \\
\hline & Batuanten & 46,10 & 8,97 & 55,08 \\
\hline Rerata & & $44,11 \mathrm{c}$ & $9,73 c$ & $53,84 b$ \\
\hline \multirow{5}{*}{ Kebasen } & Gambarsari & 32,61 & 8,64 & 41,24 \\
\hline & Kebasen & 41,94 & 9,73 & 51,67 \\
\hline & Cindaga & 44,62 & 4,75 & 49,37 \\
\hline & Randegan & 54,00 & 7,39 & 61,39 \\
\hline & Kalisalak & 34,35 & 18,35 & 52,71 \\
\hline Rerata & & $41,51 \mathrm{~b}$ & $9,77 \mathrm{c}$ & $51,28 \mathrm{a}$ \\
\hline \multirow{5}{*}{ Sumpiuh } & Lebeng & 48,50 & 0,00 & 48,50 \\
\hline & Kuntili & 50,74 & 3,91 & 54,65 \\
\hline & Kemiri & 51,85 & 3,08 & 54,93 \\
\hline & Selandaka & 64,15 & 0,00 & 64,15 \\
\hline & Karanggedang & 56,62 & 0,00 & 56,62 \\
\hline Rerata & & $54,37 d$ & $1,40 \mathrm{a}$ & $55,77 b$ \\
\hline \multirow{5}{*}{ Kembaran } & Karangtengah & 43,99 & 15,15 & 59,14 \\
\hline & Purwodadi & 49,46 & 2,86 & 52,32 \\
\hline & Kembaran & 26,38 & 25,44 & 51,82 \\
\hline & Pliken & 28,71 & 19,37 & 48,08 \\
\hline & Ledug & 32,56 & 31,40 & 63,96 \\
\hline Rerata & & $36,22 a$ & $18,84 d$ & $55,06 \mathrm{~b}$ \\
\hline
\end{tabular}

Keterangan: angka yang diikuti huruf yang sama pada satu kolom menunjukkan tidak berbeda nyata pada uji DMRT taraf kesalahan $5 \%$

Hal ini sesuai dengan pendapat Wang et al. (2008) yang melaporkan bahwa klorpirifos memiliki toksisitas tertinggi terhadap Anagrus nilaparvatae dan imidakloprid adalah insektisida yang paling beracun kedua, sementara insect growth regulators (IGR) memiliki toksisitas terendah. Toksisitas oral diklorvos terhadap A. nilaparvatae paling tinggi dengan angka kematian $100 \%$ hanya dalam waktu 2 jam setelah perlakuan. Isoprokarb, imidakloprid, dan tiametoksam adalah insektisida yang paling beracun kedua dan membunuh semua $A$. nilaparvatae dalam waktu 4 jam. Imidakloprid adalah insektisida yang persisten dan masih mampu meracuni $A$. nilaparvatae dengan kematian mencapai $80,7 \%$ pada 7 hari setelah perlakuan. Insektisida dengan bahan aktif tiametoksam, triazofos, dan fipronil juga memiliki toksisitas residu pada 7 hari setelah perlakuan dan menimbulkan kematian berturut-turut $66,8 \% ; 54,6 \%$; dan $50,0 \%$. Sementara itu, intensitas serangan hama wereng batang cokelat dan populasinya bervariasi dari tiap kecamatan maupun desa dalam kecamatan. Data selengkapnya intensitas serangan dan populasi hama wereng batang cokelat disajikan pada Tabel 3 dan Tabel 4.

Kemampuan kerja parasitoid dalam mengendalikan hama wereng batang cokelat di Kabupaten Banyumas secara alami tersebut dapat dilihat dari intensitas serangan dan populasi hama tersebut (Tabel 3 dan Tabel 4). Intensitas serangan hama wereng batang cokelat berkisar 6,96-23,58\%, sedangkan populasi wereng batang cokelat berkisar 0,84-27,36 individu per rumpun. Menurut Kushwaha et al. (2016), 
Tabel 3. Rerata intensitas serangan hama wereng batang cokelat pada desa dan kecamatan sampel

\begin{tabular}{|c|c|c|c|}
\hline Kecamatan & Desa & $\begin{array}{l}\text { Intensitas serangan } \\
\text { pada setiap desa (\%) }\end{array}$ & $\begin{array}{c}\text { Intensitas serangan } \\
\text { pada setiap kecamatan }(\%)\end{array}$ \\
\hline \multirow[t]{5}{*}{ Jatilawang } & Karanganyar & $9,38 d$ & $16,52 \mathrm{e}$ \\
\hline & Margasana & $22,43 q$ & \\
\hline & Kedungwringin & $13,89 \mathrm{r}$ & \\
\hline & Bantar & $13,35 \mathrm{r}$ & \\
\hline & Tinggarjaya & 23,581 & \\
\hline \multirow[t]{5}{*}{ Cilongok } & Kalisari & $11,52 \mathrm{j}$ & $10,20 \mathrm{a}$ \\
\hline & Rancamaya & $8,49 \mathrm{c}$ & \\
\hline & Sudimara & $6,96 a$ & \\
\hline & Panusupan & $12,41 \mathrm{k}$ & \\
\hline & Batuanten & $11,65 j$ & \\
\hline \multirow[t]{5}{*}{ Kebasen } & Gambarsari & $10,03 \mathrm{f}$ & $12,07 \mathrm{c}$ \\
\hline & Kebasen & $8,08 \mathrm{~b}$ & \\
\hline & Cindaga & $16,59 n$ & \\
\hline & Randegan & $15,07 \mathrm{~m}$ & \\
\hline & Kalisalak & $10,59 \mathrm{~g}$ & \\
\hline \multirow[t]{5}{*}{ Sumpiuh } & Lebeng & 19,990 & $15,45 d$ \\
\hline & Kuntili & $21,85 p$ & \\
\hline & Kemiri & $11,52 \mathrm{j}$ & \\
\hline & Selandaka & $12,32 \mathrm{k}$ & \\
\hline & Karanggedang & $11,58 \mathrm{j}$ & \\
\hline \multirow[t]{5}{*}{ Kembaran } & Karangtengah & $11,26 \mathrm{~h}$ & $10,47 b$ \\
\hline & Purwodadi & $9,55 \mathrm{e}$ & \\
\hline & Kembaran & $11,49 \mathrm{i}$ & \\
\hline & Pliken & $8,47 \mathrm{c}$ & \\
\hline & Ledug & $11,59 \mathrm{j}$ & \\
\hline
\end{tabular}

Keterangan: angka yang diikuti huruf yang sama pada satu kolom menunjukkan tidak berbeda nyata pada uji DMRT taraf kesalahan $5 \%$

jika wereng batang cokelat pada pesemaian sekitar 5-10 nimfa/rumpun dan 15-20 individu wereng batang cokelat per rumpun dapat menyebabkan daun bagian bawah menguning, layu dan akhirnya mati. Sedangkan menurut Prakash et al. (2014), ambang ekonomi wereng batang cokelat adalah 10 15 wereng/rumpun. Hasil pengamatan menunjukkan bahwa populasi wereng batang cokelat di Desa Margasana (Kecamatan Jatilawang), Desa Panusupan (Kecamatan Cilongok), Desa Cindaga dan Randegan (Kecamatan Kebasen), Desa Lebeng (Kecamatan Sumpiuh) sudah di atas ambang ekonomi. Secara umum populasi wereng batang cokelat di enam kecamatan sampel masih di bawah ambang ekonomi (Tabel 4).

Intensitas serangan hama wereng batang cokelat berbeda nyata pada setiap kecamatan dan desa dalam kecamatan. Intensitas serangan tertinggi terjadi di Kecamatan Jatilawang sebesar 16,52\%, sedangkan untuk desa dengan intensitas serangan tertinggi di Desa Tinggarjaya, Kecamatan Jatilawang sebesar $23,8 \%$. Hal ini terjadi karena petani tidak menanam padi secara serempak sehingga siklus hama wereng batang cokelat tidak terputus (Tabel 5). Di sekitar tanaman perangkap diletakkan, umur tanaman padi tidak seragam.

Selain itu, petani juga masih menanam varietas IR 64 yang sudah terpatahkan ketahanannya dan menggunakan insektidida kimia sintetis yang berlebihan. Kebanyakan petani menggunakan insektisida kimia sintetis sejak tanaman masih di pesemaian sebanyak 2-10 kali aplikasi (Tabel 6). Selain itu penggunaan dosis insektisida tidak lagi sesuai dengan anjuran pada kemasan, karena pada dosis tersebut tidak dapat menekan populasi hama. Penggunaan dosis dapat dua sampai tiga kali dosis anjuran. Penggunaan insektisida yang berlebihan ini sebagai upaya untuk melindungi tanaman padinya dari serangan hama wereng batang cokelat karena pada musim tanam sebelumnya populasi hama wereng batang cokelat di daerah tersebut tinggi. Penggunaan insektisida di desa ini juga berpengaruh terhadap tingkat pemarasitan parasitoid pada 
Tabel 4. Rerata populasi hama wereng batang cokelat (WBC) pada desa dan kecamatan sampel

\begin{tabular}{|c|c|c|c|}
\hline Kecamatan & Desa & $\begin{array}{c}\text { Populasi WBC per rumpun } \\
\text { pada setiap desa }\end{array}$ & $\begin{array}{l}\text { Populasi WBC per rumpun } \\
\text { pada setiap kecamatan }\end{array}$ \\
\hline Jatilawang & $\begin{array}{l}\text { Karanganyar } \\
\text { Margasana } \\
\text { Kedungwringin } \\
\text { Bantar } \\
\text { Tinggarjaya }\end{array}$ & $\begin{array}{r}4,18 \mathrm{c} \\
11,72 \mathrm{c} \\
3,87 \mathrm{c} \\
2,42 \mathrm{c} \\
2,38 \mathrm{c}\end{array}$ & $4,91 \mathrm{a}$ \\
\hline Cilongok & $\begin{array}{l}\text { Kalisari } \\
\text { Rancamaya } \\
\text { Sudimara } \\
\text { Panusupan } \\
\text { Batuanten }\end{array}$ & $\begin{array}{r}0,90 \mathrm{a} \\
\mathbf{0 , 8 4 a} \\
2,60 \mathrm{c} \\
\mathbf{2 7 , 3 6 e} \\
5,66 \mathrm{c}\end{array}$ & $7,47 \mathrm{c}$ \\
\hline Kebasen & $\begin{array}{l}\text { Gambarsari } \\
\text { Kebasen } \\
\text { Cindaga } \\
\text { Randegan } \\
\text { Kalisalak }\end{array}$ & $\begin{array}{r}7,28 \mathrm{c} \\
5,06 \mathrm{c} \\
11,00 \mathrm{c} \\
20,16 \mathrm{~d} \\
6,10 \mathrm{c}\end{array}$ & $9,92 d$ \\
\hline Sumpiuh & $\begin{array}{l}\text { Lebeng } \\
\text { Kuntili } \\
\text { Kemiri } \\
\text { Selandaka } \\
\text { Karanggedang }\end{array}$ & $\begin{array}{r}10,16 \mathrm{c} \\
2,18 \mathrm{~b} \\
3,02 \mathrm{c} \\
9,82 \mathrm{c} \\
9,04 \mathrm{c}\end{array}$ & $6,84 b$ \\
\hline Kembaran & $\begin{array}{l}\text { Karangtengah } \\
\text { Purwodadi } \\
\text { Kembaran } \\
\text { Pliken } \\
\text { Ledug }\end{array}$ & $\begin{array}{l}8,14 \mathrm{c} \\
2,06 \mathrm{~b} \\
2,56 \mathrm{c} \\
3,18 \mathrm{c} \\
3,34 \mathrm{c}\end{array}$ & $3,86 \mathrm{a}$ \\
\hline
\end{tabular}

Keterangan: angka yang diikuti huruf yang sama pada satu kolom menunjukkan tidak berbeda nyata pada uji DMRT taraf kesalahan $5 \%$

tanaman perangkap. Tingkat pemarasitan parasitoid pada tanaman perangkap di Desa Tinggarjaya lebih rendah dibanding desa yang lain dalam satu kecamatan yaitu 48,24\% (Tabel 2).

Wereng batang cokelat di Desa Tinggarjaya, Kecamatan Jatilawang diduga sudah mengalami resistensi terhadap beberapa jenis insektisida. Hasil survei yang dilakukan peneliti menunjukkan bahwa petani di Desa Tinggarjaya menggunakan insektisida berbahan aktif imidakloprid, klorpirifos, fipronil, nitenpyram, dan pymetrozine (Tabel 6). Pada saat di pesemaian dan fase vegetatif, petani menggunakan insektisida berbahan aktif imidakloprid, klorpirifos, fipronil untuk mengendalikan hama wereng batang cokelat, namun populasinya tidak dapat ditekan bahkan semakin meningkat. Petani kemudian menggunakan insektisida berbahan aktif nitenpyram dan pymetrozine untuk menyelamatkan tanaman padinya. Kondisi tersebut sesuai dengan hasil penelitian Sutrisno (2014) yang menunjukkan bahwa wereng batang cokelat di Indonesia sudah mengalami resistensi terhadap insektisida BPMC, karbofuran, MIPC, dan imidakloprid. Hasil penelitian Baehaki et al. (2016) menunjukkan bahwa penggunaan insektisida imidakloprid, buprofezin, tiametoksam, dan sipermetrin dalam pengendalian wereng batang cokelat populasi Sukamandi tidak menguntungkan karena nilai rasio resistensi (RR) $>4$. Penggunaan insektisida imidakloprid, etiprol, buprofezin, fipronil, sipermetrin, dan sihalothrin untuk mengendalikan wereng batang cokelat populasi Juwiring juga tidak menguntungkan karena nilai $R R>4$. Sedangkan hasil penelitian Surahman et al. (2016) menunjukkan bahwa telah terjadi resistensi wereng batang cokelat terhadap insektisida imida-kloprid di Serang, Karawang, Subang, Indramayu, dan Purbalingga.

Menurut Ikeda dan Vaughan (2004) serta Baehaki dan Munawar (2008), hama wereng batang cokelat mempunyai plastisitas genetik yang tinggi, sehingga mampu beradaptasi dengan berbagai lingkungan pada waktu yang relatif singkat. Hal ini 
Tabel 5. Varietas, pola tanam dan waktu tanam padi di Kabupaten Banyumas pada musim tanam April-September 2017

\begin{tabular}{|c|c|c|c|c|c|}
\hline No. & Kecamatan & Desa & Varietas yang ditanam & Pola tanam & Waktu tanam \\
\hline \multirow[t]{5}{*}{1} & \multirow[t]{5}{*}{ Jatilawang } & Karanganyar & HT, Mekongga & padi-padi-padi & Tidak serempak \\
\hline & & Margasana & $\begin{array}{l}\text { HT, IR 64, Ciherang, } \\
\text { Inpago Unsoed } 1\end{array}$ & padi-padi-padi & Tidak serempak \\
\hline & & Kedungwringin & $\begin{array}{l}\text { HT, Mekongga, } \\
\text { Ciherang }\end{array}$ & padi-padi-padi & Tidak serempak \\
\hline & & Bantar & $\begin{array}{l}\text { HT, Mekongga, } \\
\text { Ciherang, IR } 64\end{array}$ & padi-padi-padi & Tidak serempak \\
\hline & & Tinggarjaya & IR 64, Mekongga & padi-padi-padi & Tidak serempak \\
\hline \multirow[t]{5}{*}{2} & \multirow[t]{5}{*}{ Cilongok } & Kalisari & $\begin{array}{l}\text { Logawa, Situbagendit, } \\
\text { IR64, Mekongga }\end{array}$ & padi-padi-padi & Tidak serempak \\
\hline & & Rancamaya & Ciherang, Situbagendit & padi-padi-padi & Relatif serempak \\
\hline & & Sudimara & Mekongga, Ciliwung & padi-padi-padi & Relatif serempak \\
\hline & & Panusupan & Mekongga, Situbagendit & padi-padi-padi & Tidak serempak \\
\hline & & Batuanten & $\begin{array}{l}\text { Mekongga, Rajawali, } \\
\text { Ciherang }\end{array}$ & padi-padi-padi & Tidak serempak \\
\hline \multirow[t]{5}{*}{3} & \multirow[t]{5}{*}{ Kebasen } & Gambarsari & Mekongga & padi-padi-padi & Tidak serempak \\
\hline & & Kebasen & $\begin{array}{l}\text { Ciherang, IR 64, } \\
\text { Pandan wangi }\end{array}$ & padi-padi-palawija & Tidak serempak \\
\hline & & Cindaga & Ciherang & padi-padi-padi & Tidak serempak \\
\hline & & Randegan & IR 64, Ciherang & padi-padi-padi & Tidak serempak \\
\hline & & Kalisalak & Ciherang & padi-padi-kedelai & Tidak serempak \\
\hline \multirow[t]{5}{*}{4} & \multirow[t]{5}{*}{ Sumpiuh } & Lebeng & $\begin{array}{l}\text { Logawa, Situbagendit, } \\
\text { IR64, Ciherang }\end{array}$ & padi-padi-padi & Tidak serempak \\
\hline & & Kuntili & Ciherang, Situbagendit & padi-padi-padi & Tidak serempak \\
\hline & & Kemiri & Ciherang, Situbagendit & padi-padi-padi & Tidak serempak \\
\hline & & Selandaka & Ciherang & padi-padi-padi & Tidak serempak \\
\hline & & Karanggedang & $\begin{array}{l}\text { Pak Tiwi, Situbagendit, } \\
\text { Mekongga }\end{array}$ & Padi-padi-padi & Tidak serempak \\
\hline \multirow[t]{5}{*}{5} & \multirow[t]{5}{*}{ Kembaran } & Karangtengah & Situbagendit, IR 64 & padi-padi-padi & Tidak serempak \\
\hline & & Purwodadi & Situbagendit, IR 64 & padi-padi-palawija & Tidak serempak \\
\hline & & Kembaran & Mekongga, IR 64 & padi-padi-padi & Tidak serempak \\
\hline & & Pliken & Situbagendit, IR 64 & padi-padi-palawija & Tidak serempak \\
\hline & & Ledug & Mekongga, IR 64 & padi-padi-padi & Tidak serempak \\
\hline
\end{tabular}

terbukti dengan timbulnya biotipe/populasi baru yang dapat mengatasi sifat ketahanan atau hama tersebut menjadi resisten terhadap insektisida. Penanaman VUTW yang memiliki gen tahan (Bph), ketahanannya patah hanya dalam 3-4 musim tanam, karena munculnya biotipe wereng batang cokelat. Selain itu petani juga banyak menggunakan insektisida kimia sintetis yang menyebabkan hama menjadi resisten dan terbunuhnya musuh alami.

Intensitas serangan wereng batang cokelat terendah terjadi di Desa Sudimara, Kecamatan Cilongok yaitu $6,96 \%$. Rendahnya intensitas serangan di Desa Sudimara diduga karena petani di Desa Sudimara menanam padi secara serempak dalam areal yang luas. Selisih umur tanam tidak lebih dari dua minggu. Rendahnya intensitas serangan sejalan dengan rendahnya populasi wereng batang cokelat $(2,60$ individu/rumpun) dan tingginya tingkat pemarasitan parasitoid telur yaitu 42,96\% (Gambar 1). Musuh alami khususnya parasitoid telur bekerja secara tergantung kepadatan hama. Secara alami parasitoid sudah bekerja mengendalikan populasi hama wereng batang cokelat. Hal ini sesuai dengan pendapat Untung (2006) yang menyatakan musuh alami sebagai bagian dari agroekosistem memiliki peranan menentukan dalam pengaturan dan pengendalian populasi hama. Sebagai faktor yang bekerja tergantung dari kepadatan yang tidak lengkap (imperfectly density dependent) dalam kisaran tertentu, populasi musuh alami dapat mempertahankan keberadaannya di sekitar batas keseimbangan dan mekanisme umpan balik negatif. 
Tabel 6. Pemakaian insektisida kimia di Kabupaten Banyumas dalam mengendalikan hama wereng batang cokelat pada musim tanam April-September 2017

\begin{tabular}{|c|c|c|c|c|c|}
\hline No. & Kecamatan & Desa & Waktu aplikasi & $\begin{array}{c}\text { Frekuensi } \\
\text { aplikasi/ } \\
\text { musim tanam }\end{array}$ & $\begin{array}{l}\text { Bahan aktif insektisida } \\
\text { yang digunakan }\end{array}$ \\
\hline \multirow[t]{5}{*}{1} & \multirow[t]{5}{*}{ Jatilawang } & Karanganyar & Pesemaian-tanam & $2-7$ kali & $\begin{array}{l}\text { klorpirifos }+ \text { sipermetrin, alfametrin, } \\
\text { nitenpyram, pymetrozine }\end{array}$ \\
\hline & & Margasana & Pesemaian-tanam & 3-7 kali & $\begin{array}{l}\text { pymetrozine, nitenpyram, } \\
\text { klorpirifos }+ \text { sipermetrin }\end{array}$ \\
\hline & & Kedungwringin & Pesemaian-tanam & 4-7 kali & sipermetrin, pymetrozine, alfametrin \\
\hline & & Bantar & Pesemaian-tanam & $3-6$ kali & fenobukarb, lamda sihalotrin \\
\hline & & Tinggarjaya & Pesemaian-tanam & $3-10$ kali & $\begin{array}{l}\text { imidakloprid, klorpirifos, fipronil, } \\
\text { nitenpyram, dan pymetrozine }\end{array}$ \\
\hline \multirow[t]{5}{*}{2} & \multirow[t]{5}{*}{ Cilongok } & Kalisari & Pesemaian-tanam & $2-5$ kali & fipronil \\
\hline & & Rancamaya & Pesemaian-tanam & $2-4$ kali & fipronil,metomil, etofenproks \\
\hline & & Sudimara & Pesemaian-tanam & $2-4$ kali & metomil, sipermetrin \\
\hline & & Panusupan & Pesemaian-tanam & $2-6$ kali & klorpirifos + sipermetrin, fipronil \\
\hline & & Batuanten & Pesemaian-tanam & $2-5$ kali & klorpirifos + sipermetrin, fipronil \\
\hline \multirow[t]{5}{*}{3} & \multirow[t]{5}{*}{ Kebasen } & Gambarsari & Pesemaian-tanam & $2-7$ kali & $\begin{array}{l}\text { pymetrozine, nitenpyram, } \\
\text { klorpirifos }+ \text { sipermetrin }\end{array}$ \\
\hline & & Kebasen & Pesemaian-tanam & $2-7$ kali & nitenpyram, dimehipo,pymetrozine \\
\hline & & Cindaga & Pesemaian-tanam & $2-7$ kali & $\begin{array}{l}\text { pymetrozine, nitenpyram, klorpirifos }+ \\
\text { sipermetrin, buprofezin }\end{array}$ \\
\hline & & Randegan & Pesemaian-tanam & $2-6$ kali & $\begin{array}{l}\text { pymetrozine, nitenpyram, } \\
\text { klorpirifos }+ \text { sipermetrin }\end{array}$ \\
\hline & & Kalisalak & Pesemaian-tanam & $2-6$ kali & nitenpyram \\
\hline \multirow[t]{5}{*}{4} & \multirow[t]{5}{*}{ Sumpiuh } & Lebeng & Pesemaian-tanam & $2-7$ kali & $\begin{array}{l}\text { pymetrozine, nitenpyram, } \\
\text { klorpirifos + sipermetrin }\end{array}$ \\
\hline & & Kuntili & Pesemaian-tanam & $2-7$ kali & $\begin{array}{l}\text { pymetrozine, nitenpyram, } \\
\text { klorpirifos }+ \text { sipermetrin }\end{array}$ \\
\hline & & Kemiri & Pesemaian-tanam & $2-7$ kali & $\begin{array}{l}\text { pymetrozine, nitenpyram, } \\
\text { klorpirifos }+ \text { sipermetrin }\end{array}$ \\
\hline & & Selandaka & Pesemaian-tanam & $2-7$ kali & $\begin{array}{l}\text { pymetrozine, nitenpyram, } \\
\text { klorpirifos }+ \text { sipermetrin, fenobukarb }\end{array}$ \\
\hline & & Karanggedang & Pesemaian-tanam & $2-7$ kali & $\begin{array}{l}\text { pymetrozine, nitenpyram, } \\
\text { klorpirifos + sipermetrin, } \\
\text { etofenproks, lamda sihalotrin }\end{array}$ \\
\hline \multirow[t]{5}{*}{5} & \multirow[t]{5}{*}{ Kembaran } & Karangtengah & $\begin{array}{l}\text { ada gejala di } \\
\text { pesemaian }\end{array}$ & $2-7$ kali & $\begin{array}{l}\text { nitenpyram, klorpirifos }+ \text { sipermetrin, } \\
\text { fenvalerat }\end{array}$ \\
\hline & & Purwodadi & $\begin{array}{l}\text { ada gejala di } \\
\text { pesemaian }\end{array}$ & $2-7$ kali & $\begin{array}{l}\text { nitenpyram, klorpirifos }+ \text { sipermetrin, } \\
\text { fenvalerat, BPMC }\end{array}$ \\
\hline & & Kembaran & $\begin{array}{l}\text { ada gejala di } \\
\text { pesemaian }\end{array}$ & $2-5$ kali & MIPC, nitenpyram \\
\hline & & Pliken & $\begin{array}{l}\text { ada gejala di } \\
\text { pesemaian }\end{array}$ & $2-8$ kali & $\begin{array}{l}\text { pymetrozine, nitenpyram, } \\
\text { klorpirifos + sipermetrin }\end{array}$ \\
\hline & & Ledug & $\begin{array}{l}\text { ada gejala di } \\
\text { pesemaian }\end{array}$ & $2-6$ kali & $\begin{array}{l}\text { nitenpyram, klorpirifos }+ \text { sipermetrin, } \\
\text { fenvalerat }\end{array}$ \\
\hline
\end{tabular}




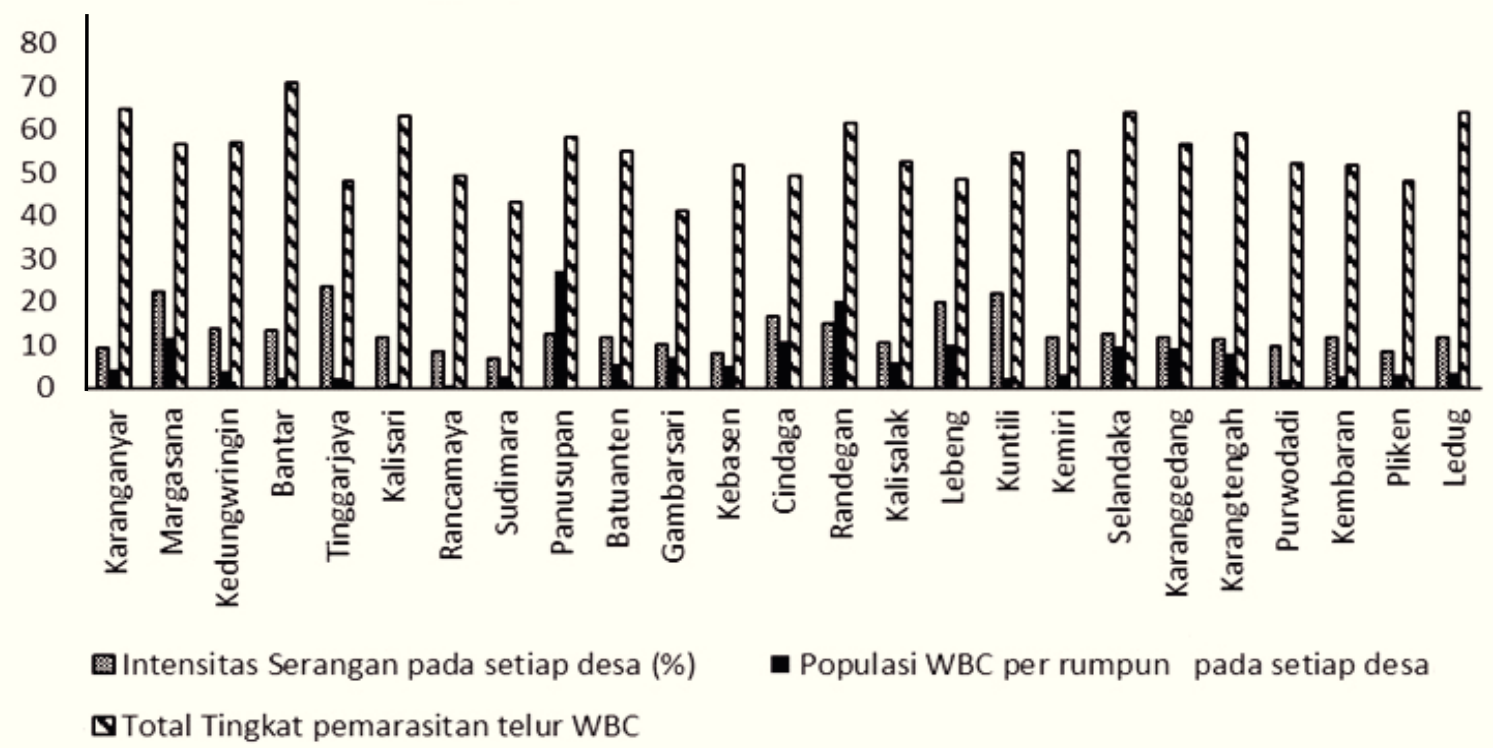

Gambar 1. Populasi dan intensitas serangan hama wereng batang cokelat (WBC) serta tingkat pemarasitan parasitoid terhadap telur wereng batang cokelat di tiap desa sampel

Kinerja parasitoid dalam mengendalikan hama wereng batang cokelat ini didukung dengan perilaku petani yang selektif dalam menggunakan insektisida kimia sintetis. Petani tidak lagi menggunakan insektisida berbahan aktif imidakloprid, klorpirifos, fipronil yang diketahui telah menimbulkan resistensi pada hama wereng batang cokelat. Petani juga mengurangi penggunaan insektisida kimia sintetis. Insektisida kimia sintetis digunakan pada saat populasi berada pada ambang ekonomi. Hal ini sesuai dengan pendapat Croft (1990) yang menyatakan selektivitas ekologis dapat dicapai dengan membatasi pemaparan pestisida terhadap musuh alami dari hama dan lingkungannya.

\section{KESIMPULAN}

Parasitoid yang ditemukan di Kabupaten Banyumas adalah Gonatocerus sp. dan Oligosita sp. dengan kemampuan memarasit sebesar 26,8-64,73\%, dan 1,82-31,40\%. Keberadaan parasitoid berpotensi menekan intensitas serangan hama wereng batang cokelat pada fase vegetatif. Intensitas serangan berkisar antara 6,96-23,58\%, dan populasi wereng batang cokelat berkisar $0,84-27,36$ individu per rumpun.

\section{UCAPAN TERIMA KASIH}

Ucapan terima kasih penulis sampaikan kepada Direktorat Riset dan Pengabdian Masyarakat, Direktorat Jenderal Penguatan Riset dan Pengembangan Kementerian Riset, Teknologi, dan Pendidikan Tinggi yang telah mendanai penelitian ini melalui skim Penelitian Produk Terapan tahun anggaran 2017, sesuai dengan Kontrak Penelitian No:11005/ UN23.14/PN/ 2017.

\section{DAFTAR PUSTAKA}

Abdillah, N.A. 2015. Keanekaragaman dan Biologi Reproduksi Parasitoid Wereng Cokelat Nilaparvata lugens Stal (Hemiptera; Delphacidae). Tesis. Sekolah Pascasarjana, Institut Pertanian Bogor, Bogor. $93 \mathrm{hlm}$.

Ali,M.P., D. Guang, G. Nachman, N. Ahmed, M.A. Begu, \& M.F. Rabbi. 2014. Will Climate Change Affect Outbreak Patterns of Planthoppers in Bangladesh? Plos One 9: e91678.

Baehaki, S.E; E.H. Iswanto, \& D. Munawar. 2016. Resistensi Wereng Cokelat terhadap Insektisida yang Beredar di Sentra Produksi Padi. Penelitian Pertanian Tanaman Pangan 35: 99-108.

Baehaki, S.E. \& I.M.J. Mejaya. 2014. Wereng Cokelat sebagai Hama Global Bernilai Ekonomi Tinggi dan Strategi Pengendaliannya. Iptek Tanaman Pangan 9: 1-12. 
Baehaki, S.E., \& D. Munawar. 2008. Uji Biotipe Wereng Cokelat Nilaparvata lugens Stal. di Sentra Produksi Padi. Seminar Pekan Padi Nasional III di Sukamandi.

Bottrell, D.G. \& K. G. Schoenly. 2012. Resurrecting the Ghost of Green Revolutions Past: the Brown Planthopper as A Recurring Threat to HighYielding Rice Production in Tropical Asia. Journal of Asia-Pacific Entomology 15: 122- 140.

Brunner, J.F., J.E. Dunley, M.D. Doerr, \& E.H. Beers. 2001. Effect of Pesticides on Colpoclypeus florus (Hymenoptera: Eulophidae) and Trichogramma platneri (Hymenoptera: Trichogrammatidae), Parasitoids of Leafrollers in Washington. Journal of Economic Entomology 94: 1075-1084.

Budi, K. 2017. Pemerintah Gerak Cepat Hadapi Serangan Wereng Coklat. https://ekonomi. kompas.com/read/2017/08/12/203032726 /pemerintah-gerak-cepat-hadapi-seranganwereng-coklat, diakses 18/12/2017.

Cheng,J. 2009. Rice Planthopper Problems and Relevant Causes in Cina, p. 157-178. In K.L. Heong \& B. Hardy (eds.), Planthopper: New Thread to the Sustainability on Intensive Rice Production System in Asia. IRRI-ADB-Australiant Goverment: Australian Centre for International Agricultural Research.

Croft, B.A. 1990. Arthropod Biological Control Agents and Pesticides. John Wiley \& Sons,Inc. United State of America. 723 p.

Hu, S.J., D.Y. Fu, X.J. Liu, T. Zhao, Z.L. Han, J.P. Lü, H.I. Wan, \& H. Ye. 2012. Diversity of Planthoppers Associated with the Winter Rice Agroecosystems in Southern Yunnan, China. Journal of Insect Science 12: 29.

Hu, G., F. Lu., B.P.,Zhai, M.H. Lu, W.C. Liu, F. Zhu, X.W. Wu, G.H. Chen, \& X.X. Zhang. 2014. Outbreaks of the Brown Planthopper Nilaparvata lugens (Stall) in the Yangtze River Delta: Immigration or Local Reproduction? Plos One 9: e88973.

Haryati, S., Y. A. Trisyono, \& Witjaksono. 2016. Parasitism of the Rice Brown Planthopper Eggs in Various Periods of Time of the Day. Jurnal Perlindungan Tanaman Indonesia 20: 28-35.

Ikeda, R \& D.A. Vaughan. 2004. The Distribution of Resistance Genes to the Brown Planthopper in Rice Germplasm. Rice Genetics Newsletter 8: 125-127.

International Rice Research Institute. 2002. Standart Evaluation System for Rice (SES). http://www.knowledgebank.irri.org/images/ docs/rice-standard-evaluation-system.pdf, diakses $18 / 12 / 2017$.
Kushwaha,R.K., S. Sharma \& P.K. Sharma. 2016. Determination of Economic Threshold Level (ETL) of Brown Planthopper, Nilaparvata lugens Stal. Population in Different Stages of Rice Crop at Raipur. International Journal of Plant Protection 9: 115-119.

Lu, Z.X, S. Villareal , Y. Xiao-Ping, K. L. Heong, \& H. Cui. 2006. Biodiversity and Dynamics of Planthoppers and Their Natural Enemies in Rice Fields with Different Nitrogen Regimes. Rice Science 13: 218-226

Meilin, A., Y. A. Trisyono, E. Martono, \& D. Buchori. 2012. The Effects of Deltamethrin Applied at Sublethal Concentrations on the Adults of Anagrus nilaparvatae (Hymenoptera: Mymaridae). ARPN Journal of Agricultural and Biological Science 7: 1032-1037.

Munawar,D., E. H. Iswanto, N. Sumaryono, \& S.E. Baehaki. 2015. Laju Parasitasi Parasitoid Anagrus sp. dan Oligosita sp. terhadap Telur Wereng Cokelat setelah Aplikasi Insektisida di Pertanaman Padi. Jurnal Agrotrop 5: 139-149.

Piyaphongkul, J., J. Pritchard, \& J. Bale. 2012. Heat Stress Impedes Development and Lowers Fecundity of the Brown Planthopper Nilaparvata lugens (Stall). Plos One 7: e47413.

Preetha, G., J.Stanley, S.Suresh, \& R.Samiyappan. 2010. Risk Assessment of Insecticides Used in Rice on Miridbug, Cyrtorhinus lividipennis Reuter, the Important Predator of Brown Planthopper Nilaparvata lugens (Stal.). Chemosphere 80: 498-503.

Prakash,A., J.S. Bentur, M.S. Prasad, R.K. Tanwar, O.P. Sharma, S. Bhagat, M. Sehgal, S.P. Singh, C. Chattopadhyay, S.N. Sushil, A.K. Sinha, R. Asre, K.S. Kapoor, K. Satyagopal, \& P. Jeyakumar. 2014. Integrated Pest Management for Rice. National Centre of Integrated Pest Management, Rajendranagar, LBS Building, IARI Campus, Pusa, New Delhi. 43 p.

Quicke, D.L.J. 1997. Parasitic Wasps. Chapman and Hall Ltd. London, UK. 470 p.

Surahman, E.C., Dadang, \& D. Prijono. 2016. Kerentanan Wereng Batang Cokelat, Nilaparvata lugens Stal. (Hemiptera: Delphacidae), dari Enam Lokasi di Pulau Jawa terhadap Tiga Jenis Insektisida. Jurnal Hama Penyakit Tumbuhan Tropika 16: 71-81.

Sutrisno. 2014. Resistensi Wereng Batang Cokelat Padi, Nilaparvata lugens Stal. terhadap Insektisida di Indonesia. Jurnal Agro Biogen 10: 115-124. 
Tiwari, S.N. 2015. Identification of New Sources of Resistance against Brown Planthopper. Journal of Plant Science and Research 2: 1-5.

Townsend \& Hueberger. 1948. The Basic Principles of Crop Protection Field Trials. Pflanzenschutz Nachrichten Bayer AG Leverkusen.
Untung,K. 2006. Pengantar Pengelolaan Hama Terpadu. Gadjah Mada University Press, Yogyakarta, $348 \mathrm{hlm}$.

Wang, H.Y., Y. Yang, J. Y. Su, J.L. Shen, C. F. Gao, \& Y. C.Zhu. 2008. Assessment of the Impact of Insecticides on Anagrus nilaparvatae (Pang et Wang) (Hymenoptera: Mymanidae), an Egg Parasitoid of the Rice Planthopper, Nilaparvata lugens (Hemiptera: Delphacidae). Journal of Crop Protection 27: 514-522. 